\title{
Konseling Cyber: Sebuah Model Konseling Pada Konteks Masyarakat Berbasis Online
}

\author{
Hasan Bastomi \\ IAIN Kudus, Jawa Tengah, Indonesia \\ bastommy@stainkudus.ac.id
}

\begin{abstract}
Abstrak
Satu dekade belakangan dunia maya nampak tengah menjadi salah satu area terpenting dalam kehidupan manusia. Realitas virtual yang salah satunya berkembang dari evolusi internet menciptakan sebuah ruang virtual yang dapat menjadi representasi ataupun simulasi dari kehidupan nyata, termasuk dalam bidang bimbingan dan konseling yang disebut konseling cyber. Layanan konseling cyber adalah salah satu strategi layanan konseling yang bersifat virtual atau konseling yang berlangsung melalui bantuan koneksi internet. Konseling Cyber adalah jawaban dimana dewasa ini, hampir bisa dipastikan bahwa setiap orang yang memiliki telepon pintar, juga mempunyai akun media sosial, seperti Facebook, Twitter, Path, Instagram, dan sebagainya. Tetapi proses konseling dapat terjadi secara terpisah antara konselor dan konseli dalam ruang dan waktu yang berbeda. Dalam implementasi konseling cyber beberapa masalah seperti Isuisu etika dan Isu-isu pengembangan hubungan konseling mungkin timbul dan harus diwaspadai secara cermat. Oleh karena itu Konselor cyber sebaiknya memiliki kemampuan konseling cyber.
\end{abstract}

Kata Kunci: Konseling Cyber, Masyarakat Berbasis Online

\begin{abstract}
Cyber Counselling: A Model of Counselling in the Online-Based Society Context. A decade lately the virtual world appears to be one of the most important aspect in human life. Virtual reality, one of which developed from the evolution of the internet creates a virtual space that can be a representation or simulation of real life, including in the field of guidance and counselling called cyber counselling. Cyber counselling services are one of the virtual counselling service strategies or
\end{abstract}


counselling that takes place by using an internet connection. Cyber Counselling is the alternative way when today, almost everyone who has a smartphone, also has social media accounts, such as Facebook, Twitter, Path, Instagram, and so on. Nevertheless, the counselling process can occur separately between counsellors and counselees in different time and place. In implementing cyber counselling a number of issues such as ethical issues and issues of developing counselling relationship may arise and must be considered. Therefore, cyber counsellors should have the ability of cyber counselling.

Keywords: Cyber Counselling, Online Based Society

\section{A. Pendahuluan}

Satu dekade belakangan dunia maya nampak tengah menjadi salah satu area terpenting dalam kehidupan manusia. Media ini memungkinkan sebuah masyarakat kosmopolitan terbentuk walaupun dalam bentuk yang tidak nyata. Dalam dunia maya, letak geografis tidak lagi menjadi yang utama dan kecepatan arus komunikasi menjadi sebuah determinan penting dalam keterhubungan tersebut. Kebebasan menjadi unsur yang sering digaungkan dalam masa kejayaan dunia maya. Dunia maya dipandang sebagai dunia virtual yang tak berbatas dan tidak memiliki hukum. Hal ini diungkapkan Lawrence Lessig dalam Laws of Cyberspace (1998) dan John Perry Barlow dalam Declaration of Independence of Cyberspace (1996) (Henry \& David, 2003: 398). Mudah, murah, dan cepat. Itulah tiga sifat yang dapat menggambarkan sifat dunia maya saat ini. Tidak heran, terjadi perpindahan berbondong-bondong dari dunia nyata ke dunia maya, dari berbagai perihal administrasi dan bisnis hingga penggunaan fasilitas dunia maya untuk melakukan kegiatan sosial sampai politis. Dunia maya merupakan dunia alternatif yang membuka kemungkinan baru untuk berkoneksi satu sama lain.

Dalam istilah Rob Shields, realitas virtual yang salah satunya berkembang dari evolusi internet menciptakan sebuah ruang virtual yang dapat menjadi representasi ataupun simulasi dari kehidupan nyata. Shileds, seperti halnya Lessig, juga membahas mengenai kemungkinan penguasaan dalam dunia virtual tersebut yang menurutnya juga memiliki kemungkinan untuk dibatasi kebebasannya dengan pembatasa-npembatasan tertentu, walaupun tidak sepenuhnya dapat berhasil karena sulitnya melakukan pengaturan dalam dunia maya (Shields, 2003: 270). Melalui pemaparan Lessig dan Shields, didapatkan pemahaman mengenai sifat abstrak dunia maya. Dunia maya merupakan sebuah ranah yang dikendalikan 
oleh pengguna (userdriven), dan kebebasan menjadi salah satu kata kunci utama. Penentuan "pemilik" dalam dunia maya sulit dimaknai secara literal karena setiap pengguna memiliki kemungkinan melakukan perubahan atas dunia tersebut.

Perkembangan teknologi dunia maya terus meningkat dalam beberapa tahun terakhir. Ruang lingkupnya terus meluas dengan jumlah pengguna yang bertambah seiring mudah dan murahnya akses bisa didapatkan. Dua hal yang kemudian menjadi pemicu memasyarakatnya dunia maya adalah situs-situs jejaring sosial dan kemunculan blog sebagai sebuah ranah pribadi berlaku sebagai identitas baru dalam dunia maya. Pertama adalah situs jejaring sosial, yang pada awalnya terinspirasi dari konsep Six Degress Separation yang dikeluarkan melalui eksperimen yang dilakukan Stanley Milgram pada tahun 1967 (Christakis \& Fowler, 2009: 94), kemudian berkembang dari sebuah jalur media untuk membuat identitas di ranah dunia maya yang berfungsi sebagai media pertemanan ataupun pencarian pasangan berubah menjadi sebuah jalur informasi yang efektivitasnya telah teruji dalam menyebarkan berita sampai menggalang massa. Situs jejaring sosial kemudian memunculkan sebuah konsep networked public yang oleh Danah Byod (2011), diartikan sebagai publik yang terbentuk dari teknologi jejaring yang memiliki dua prasyarat, ruangnya dikonstruksi lewat teknologi jejaring dan merupakan kumpulan imajiner yang tercipta dari interseksi manusia, teknologi, dan praktik. Jaringan publik (networked public) berfungsi layaknya masyarakat di dunia nyata, tetapi aspek teknologi menciptakan bentuk interaksi baru yang kemudian membentuk kemungkinan-kemungkinan yang berujung pada dinamika baru yang membentuk partisipasi di dalamnya (Papacharissi, 2011: 39-58). Dinamika baru yang dimaksud adalah cara-cara baru berpartisipasi, misalnya dalam kasus gerakan sosial, jumlah anggota dalam fitur group pada situs Facebook, lama sebuah isu bertahan dalam trending-topic dalam situs micro-blog Twitter, juga jumlah yang menonton ataupun share dari sebuah video di situs Youtube menjadi tolok ukur baru dalam kesuksesannya.

Perkembangan teknologi komunikasi yang sangat pesat menjadikan masyarakat dunia telah bergerak dan beralih dari era tradisional, industrialisasi ke era informasi yang berujung pada hadirnya masyarakat informasi (information society). Rogers menyatakan bahwa masyarakat informasi adalah sebuah masyarakat yang sebagian besar angkatan kerjanya adalah pekerja di bidang informasi, dan informasi telah menjadi elemen yang dianggap paling penting dalam kehidupan (Rogers, 2003: 11). Revolusi informasi, biasanya dipahami sebagai perubahan yang dihasilkan oleh teknologi informasi. Dua bentuk teknologi 
komunikasi manusia yang terpenting adalah teknologi untuk menyalurkan informasi dan sistem komputer modern untuk memprosesnya. Dikatakan revolusi karena dapat memberikan perubahan yang amat cepat dalam kehidupan manusia. Terdapat dua faktor yang mendasari dan mengarahkan revolusi informasi yang dapat mempengaruhi struktur kekuasaan dunia, yaitu: Pertama, perkembangan yang cepat serta penyebaran yang luas dari pengetahuan dan informasi dalam segala bidang. Kedua, peningkatan pentingnya pengetahuan dalam produksi kekayaan serta penurunan relatif dari nilai sumber-sumber material (Ahmad, 2013: 178). Sungguh disayangkan jika perkembangan teknologi sudah berkembang sedemikian pesat namun belum dimanfaatkan dalam pelaksanaan layanan bimbingan dan konseling yang dalam prakteknya masih menggunakan cara yang masih bersifat konfensional. Oleh karena itu, yang menjadi problem adalah bagaimana mengintegrasikan teknologi informasi dengan pelaksanaan layanan konseling sehingga harapannya pelaksanaan konseling dapat berjalan dengan efektif dan efisien.

\section{B. Pembahasan}

\section{Bimbingan dan konseling}

Konseling dari segi terminologi, menurut James F. Adams, konseling adalah: "suatu pertalian timbal balik antara dua orang individu dimana yang seorang (counsellor) membantu yang lain (counselee), supaya ia dapat lebih baik memhami dirinya dalam hubungan masalah-masalah hidup yang dihadapinya pada waktu itu dan yang akan datang (Arifin, 1976: 18). Di samping itu istilah bimbingan selalu dirangkaikan dengan istilah konseling. Hal ini disebabkan karena bimbingan dan konseling itu merupakan suatu kegiatan yang integral (utuh atau melengkapi). Konseling merupakan salah satu teknik dalam pelayanan bimbingan diantara beberapa teknik lainnya. Bimbingan itu lebih luas dan konseling merupakan alat yang paling penting dari usaha pelayanan bimbingan. Pengertian konseling menurut terminologi diantaranya sebagai berikut:

Menurut James F Adams yang dikutip oleh I Djumhur dan Moh. Surya dikatakan bahwasanya: Konseling adalah suatu pertalian timbal balik antara dua orang individu di mana yang seorang (counsellor) membantu yang lain (counselee), supaya ia dapat lebih memahami dirinya dalam hubungannya dengan masalahmasalah hidup yang dihadapi pada waktu itu dan pada waktu yang aka dating (Djumhur \& Surya, 1978: 29). 
Menurut Bimo Walgio Konseling atau penyuluhan adalah bantuan yang diberikan kepada individu dalam memecahkan masalah kehidupannya dengan wawancara, dengan cara-cara yang sesuai dengan keadaan individu untuk mencapai kehidupannya (Walgito, 1989: 5). Menurut W.S. Winkel SJ Konseling merupakan suatu saluran bagi pemberian bimbingan. Dalam rangka konseling diadakan diskusi atau pembicaraan antara seorang penyuluh (counsellor) dengan satu orang (individual counselling) atau dengan beberapa orang sekaligus (group counselling) (Winkel, 2005: 5)

Dari pendapat diatas penulis memberikan kesimpulan bahwa konseling merupakan satu pertalian timbal balik antara individu dalam memecahkan masalah kehidupannya untuk mencapai kesejahteraan hidupnya secara optimal.Jadi bimbingan menyangkut konseling dan sebaliknya konseling juga menyangkut bimbingan. Namun konseling disini diberikan secara kelompok seperti: bimbingan pada umumnya bagaimana cara belajar yang efesien dan dapat diberikan kepada seluruh kelas pada suatu waktu tertentu secara bersama-sama. Dari uraian-uraian dan teori-teori yang telah dikemukakan di atas maka dapatlah ditarik suatu kesimpulan yang efektif yaitu sebagai berikut: bimbingan konseling adalah suatu proses pemberian bantuan secara terus-menerus dalam perkembangan individual untuk mencapai kemampuan, pemahaman dan pengarahan diri, penyesuaian diri serta pemecahan masalah yang dihadapi, sehingga dapat bertindak wajar sesuai dengan tuntutan lingkungannya.

Proses Bimbingan dan Konseling di sekolah dapat berhasil apabila mempunyai tujuan yang jelas yang akan dicapainya. Bimbingan dan konseling bertujuan untuk membantu peserta didik agar dapat mencapai tujuan-tujuan perkembangannya yang meliputi aspek pribadi-sosial belajar (akademik) dan karir (Yusuf \& Nurihsan, 2006: 15). Tujuan bimbingan dan konseling di sekolah dapat di kelompokkan menjadi tiga, yaitu: tujuan umum, tujuan khusus, dan tujuan akhir.

\section{Tujuan bimbingan dan konseling secara umum}

Secara umum bimbingan dan konseling mempunyai tujuan yang sama dengan tujuan pendidikan, yaitu tercapainya perkembangan kepribadian yang optimal dan harmonis di antara unsure-unsurnya yang meliputi fisik,mental, emosional, social, dan moral, bahkan spiritual (religious). Apabila kebribadian telah berkembang secara optimal dan harmonis maka peserta didik dapat dikatakan telah dewasa. Tujuan pendidikan adalah kedewasaan, sedangkan tujuan bimbingan adalah kemandirian. Dalam ilmu pendidikan orang dewasa adalah 
orang yang mampu mandiri. Orang yang sudah mandiri adalah orang yang sudah mampu bertanggung jawab.

Tujuan bimbingan dan konseling secara khusus membantu siswa dalam: (1) Memahami dirinya, baik kekuatannya maupun kelemahannya. (2) Menentukan pilihan-pilihan yang tepat sebab kesalahan dalam menentukan pilihan dapat menimbulkan masalah baru yang mungkin lebih buruk. (3) Bimbingan dan konseling juga bertujan membantu siswa dalam mencari jalan keluar atau mengatasi masalah-masalah yang dihadapi siswa dalam kehidupannya, terumta kehidupan sekolah, aik yang menyangkut masalah belajar, masalah social, maupun masalah pribadi. (4) Hal yang penting diperlukan dalam kehidupan adalah penyesuaian diri. Bimbingan dan konseling berusaha memberikann pelayanan kepada siswa agar dapat menyesuaikan diri dengan lingkungannya, baik lingkungan alam, lingkungan sosial maupun lingkungan diri sendiri. (5) Di sekolah,bimbingan dan konseling di berikan agar siswa dapat mencapai prestasi yang optimal, khususnya prestasi belajar.

Tujuan akhir bimbingan dan konseling adalah agar siswa yang dibimbing dirinya sendiri (self-guidance). Individu dipandang telah mampu membing dirinya sendiri apabila: (1) Telah mampu memahami diri (self understanding) baik memahami kekuatan-kekuatannya ataupun kelemahan-kelemahannya. Menerima dirinya (self acceptance) dengan segala kelebihan dan kekurangannya. (3) Dapat mengarahkan diri (self direction) kepada tujuan mulia yang bermanfaat bagi kehidupannya. (4) Mengaktualisasikan potensi-potensi dirinya (self actualization, self realization) dengan cara-cara yang terpuji tanpa ada pihak-pihak yang merasa dirugikan. Apabila seseorang sudah beradapada keadaan demikian maka itulah yang dikatakan self-reliance, yaitu orang yang sudah mamu berdiri diatas kaki sendiri, orang yang mampu bertanggung jawab, orang yang sudah mandiri (independence).Kemandirian memungkinkan tercapainyakesejahteraan (walfare).Inilah tujuan akhir bimbingan dan konseling (Paimun, 2008: 19-21).

Dapat disimpulkan bahwa tujuan Bimbingan dan Konseling adalah untuk membantu siswa agar dapat memecahkan masalah yang dihadapinya dalam proses belajar mengajar, juga untuk dapat bersosialisasi dengan lingkungannya. Bimbingan dan koseling sebagai bagian dari keseluruhan program di sekolah mempunyai tertentu sejalan dengan pendidikan sekolah yang bersangkutan. Secara umum bimbingan bertujuan untuk membantu individu dalam mencapai tujuan yaitu: (1) Kebahagiaan hidup pribadi. (2) Kehidupan yang efektif dan 
produktif. (3) Kesanggupan hidup bersama orang lain. (4) Keserasian antara citacita siswa dengan kemampuan yang dimiliki (Gunarsa, 1988: 14)

Dari uraian di atas dapat diketahui bahwa tujuan bimbingan dan konseling adalah untuk mengembangkan potensi pada individu seoptimal mungkin, sesuai dengan kemampuan agar bisa menyesuaikan diri dengan lingkungannya, baik lingkungan sekolah, keluarga maupun lingkungan masyarakat.Dari keterangan diatas maka bisa disimpulkan bahwa tujuan konseling belajar sebagai berikut:Membantu siswa dalam menemukan cara-cara belajar yang efektif dan efisien, membantu siswa dalam merencanakan jadwal pelajaran secara efektif, menunjukkan cara-cara mempelajari suatu materi pelajaran, menunjukkan caracara membaca buku yang baik, membantu siswa dalam mengatasi masalah kesulitan belajar yang sedang dialami, menunjukkan cara pemanfaatan perpustakaan secara tepat, menunjukkan cara mempersiapkan diri dalam menghadapi ujian atau ulangan. Dalam hadits Nabi dijelaskan, yang artinya sebagai berikut: "Rasulullah SAW bersabda: Apabila suatu perkara diserahkan (pengelolaannya) kepada orang bukan ahlinya. Tunggu sajalah saat kehancurannya (ketidak berhasilannya)."(HR.Bukhari).

Maksud dari hadits tersebut adalah orang yang memberikan bimbingan konseling harus ahli/ prosfesional dalam bidang bimbingan konseling, supaya mencapai sasaran dan tujuan yang diharapkan. Apabila kegiatan bimbingan konseling dilaksanakan oleh orang yang bukan ahlinya, maka tidak akan mencapai hasilnya (Madhal, 2008: 152).

Sesuai dengan uraian sebelumnya bahwa bimbingan dan konseling bertujuan agar peserta didik dapat menemukan dirinya, mengenal dirinya dan mampu merencanakan masa depannya. Dalam hubungan ini bimbingan dan konseling berfungsi sebagai pemberi layanan kepada peserta didik agar masingmasing peserta didik dapat berkembang secara optimal sehingga menjadi pribadi yang utuh dan mandiri. Oleh karena itu pelayanan bimbingan dan konseling mengemban sejumlah fungsi yang hendak dipenuhi melalui kegiatan bimbingan dan konseling.

Bimbingan dan Konseling merupakan fungsi integral dalam proses belajar mengajar. Fungsi bimbingan Dewa Ketut Sukardi dalam bukunya Proses Bimbingan dan Penyuluhan di sekolah adalah: a) Fungsi Preventif (Pencegahan) adalah merupakan fungsi pencegahan terhadap timbulnya masalah dalam fungsi bagi para siswa agar terhindar dari berbagai masalah yang dapat menghambat perkembangannya. Kegiatan yang berfungsi sebagai pencegahan berupa program 
orientasi, program bimbingan karier, invesasi data dan sebagainya; b) Fungsi Penyaluran adalah fungsi agar para siswa yang dibimbing dapat berkembang secara optimal, siswa perlu dibanu mendapatkan kesempatan penyaluran pribadinya. Dalam fungsi penyaluran ini layanan yang dapat diberikan, misalnya memperoleh jurusan atau program yang tepat; c) Fungsi Penyesuaian adalah membantu tercapainya penyesuaian antara pribadi siswa dan sekolah. Kegiatan dalam layanan fungsi ini berupa orientasi sekolah dan kegiatan-kegiatan kelompok; d) Fungsi Perbaikan fungsi perbaikan berperan memberi bantuan bimbingan berusaha menghadapi masalah yang dihadapi siswa; e) Fungsi Pengembangan adalah layanan bimbingan dapat membantu para siswa dalam mengembangkan pribadinya secara terarah dan mantap. Dalam fungsi developmental ini hal-hal yang dipandang positif dijaga agar tetap baik dan mantap. Dengan demikian siswa dapat mencapai perkembangan kepribadian secara optimal (Sukardi, 1995: 8-9). Secara keseluruhan, jika semua fungsi-fungsi itu telah terlaksana dengan baik, dapatlah bahwa peserta didik akan mampu berkembang secara optimal pula. Keterpaduan semua fungsi tersebut akan sangat membantu perkembangan peserta didik.

\section{Konteks historis perilaku online}

Bisa dikatakan bahwa banyak hal telah berubah dalam dekade 10 tahun terakhir, milenium baru mungkin merupakan pernyataan yang sepertinya remeh. Namun masyarakat menjadi tenggelam dalam gaya hidup yang sering digambarkan sebagai "dekade digital," dengan menggunakan aplikasi untuk setiap keinginan, dengan alat komunikasi untuk setiap tujuan, dengan pilihan platform dan teknologi yang luas.

Pada tahun 1990, merupakan hal yang cukup untuk menarik membayangkan era baru perjalanan dunia, melalui "jalan informasi." Sekarang akses membawa masuk ke rumah-rumah penduduk dan hubungan pribadi serta profesional telah berhasil berubah. Seorang Nenek dapat menyaksikan cucunya via Skype saat cucunya beralih dari bermain Piano ke iPhone dan dengan Facebook yang menghubungkan antara suatu tempat. Pada saat yang sama, telah membuka jalan baru bekerja untuk pengusaha, peneliti, pelajar, dan pendidik, dan untuk menggunakan aplikasi komputer yang melibatkan realitas virtual.

Dalam situasi sosial, lingkungan kerja, hubungan dekat, dan forum publik sudah memasuki konteks era digital. Sebuah teknologi canggih sekarang menjamur dan menjadi antusiasme generasi muda, yang lahir dera di mana mereka dikelilingi 
oleh perangkat, jaringan, dan berbagai pilihan media, yang berbeda dengan orang dewasa, dalam kegembiraan mereka beradaptasi terhadap berbagai teknologi dan aktivitas sosial secara online.

Keadaan ini adalah kunci untuk memahami pengalaman manusia dengan berbagai komponen komunikasi dalam hubungan interpersonal, hubungan kolaboratif bersama membentuk fondasi untuk semua yang juga dapat digunakan sebagai suatu terapi. Jadi, sangat penting, dalam memfasilitasi hubungan terapeutik profesional, untuk memahami dan menghargai konteks dan perspektif. Tanpa ini kemungkinan tidak ada empati atau kepercayaan. Satu dekade yang lalu beberapa upaya awal peneliti dan online berfokus pada pemahaman bagaimana konselor online secara efektif menentukan tempat yang cocok dan baik untuk terapi. Jauh sebelum kemunculan internet, variabel seperti kesesuaian tujuan dan harapan antara psikoterapis dan pasien telah ditunjukkan untuk membentuk ketentuan yang kuat untuk hasil yang positif, ini dicapai melalui dialog yang mengarah pada tujuan, pembinaan perilaku, wawasan, analisis naratif, atau motivasi, empatik konseling. Konselor online telah beradaptasi dan mengadopsi prosedur baru untuk memastikan komunikasi yang akurat dan memungkinkan ekspresi perasaan dan mood agar akurat dan saling mengerti, agar tercipta suatu empati (Kraus, Stricker, \& Speyer, 2010: 3-5).

Dewasa ini, hampir bisa dipastikan bahwa setiap orang yang memiliki telepon pintar (smart phone), mempunyai akun media sosial, seperti Facebook, Twitter, Path, Instagram, dan sebagainya. Kondisi ini merupakan sebuah kelaziman yang mengubah bagaimana cara berkomunikasi pada era serba digital seperti sekarang. Jika dahulu, perkenalan dilakukan dengan cara konvensional, yakni (biasanya) diiringi dengan saling tukar kartu nama, sekarang setiap bertemu orang baru cenderung untuk bertukar akun media sosial atau membuat pertemanan di media sosial.

Evolusi yang terjadi di bidang teknologi maupun inovasi internet menyebabkan tidak hanya memunculkan media baru saja. Berbagai macam aspek kehidupan manusia, seperti komunikasi maupun interaksi, juga mengalami perubahan yang sebelumnya tidak pernah diduga. Dunia seolah-olah tidak memiliki batasan (borderless) - tidak ada kerahasiaan yang bisa ditutupi. Kita bisa mengetahui aktivitas orang lain melalui media sosial, sementara kita tidak kenal dan tidak pernah bertemu tatap muka atau berada di luar jaringan (luring) dengan orang tersebut (Mulawarman \& Nurfitri, 2017: 36-37). 
Media sosial bahkan menjadi "senjata baru" bagi banyak bidang. Kampanye politik pada Pemilu 2014 lalu banyak melibatkan peran media sosial. Perusahaanperusahaan saat ini memberikan perhatian khusus untuk mengelola media sosial dan menjalin hubungan yang baik dengan pelanggan mereka secara daring (dalam jaringan). Iklan menjadi berubah dari cara tradisional yang diproduksi oleh perusahaan dan tentu dengan biaya yang tidak sedikit. Hal tersebut merupakan sebuah tantangan sekaligus kenyataan yang tidak bisa dipungkiri. Kehadiran media sosial dan semakin berkembangnya jumlah pengguna dari hari ke hari memberikan fakta menarik betapa kekuatan internet bagi kehidupan (Nasrullah, 2015: 23).

Riset yang dipublikasikan oleh Crowdtap, Ipsos Media CT, dan The Wall Street Journal pada tahun 2014 melibatkan 839 responden dari usia 16 hingga 36 tahun menunjukkan bahwa jumlah waktu yang dihabiskan khalayak untuk mengakses internet dan media sosial mencapai 6 jam 46 menit per hari, melebihi aktivitas untuk mengakses media tradisional (Nasrullah, 2015: 25). Meski hanya bisa digunakan terbatas dan tanpa bermaksud membuat pernyataan bahwa inilah perilaku masyarakat dunia, hasil riset tersebut menunjukkan bahwa media tradisional tidak lagi menjadi media yang dominan diakses oleh masyarakat. Kebutuhan akan menjalin hubungan sosial di internet merupakan alasan utama yang dilakukan oleh masyarakat dalam mengakses media. Kondisi ini tidak bisa didapatkan ketika masyarakat mengakses media tradisional. Tidak mengherankan, kehadiran media sosial menjadi fenomenal. Facebook, Twitter, YouTube, Instagram hingga Path adalah beberapa ragam media sosial yang diminati oleh banyak masyarakat.

Menurut Soeparno dan Sandra (2011), dunia maya seperti laiknya media sosial merupakan sebuah revolusi besar yang mampu mengubah perilaku manusia dewasa ini, dimana relasi pertemanan serba dilakukan melalui medium digital menggunakan media baru (internet) yang dioperasikan melalui situs-situs jejaring sosial. Realitas menjadi bersifat augmented dan maya yang harus diadaptasi dan diintegrasikan dalam kacamata kajian psikologi sosial kontemporer yang ubiquitous (ada dimana-mana) serta pervasive (dapat menembus berbagai bidang ilmu dan kajian) (Soeparno, 2016: 124).

Kraus, R., Stricker, G., \& Speyer, C. (2011) menjelaskan bahwa konteks adalah kunci untuk memahami pengalaman manusia dan berbagai bentuk komunikasi dalam hubungan interpersonal (Kraus et al., 2010: 4). Keunikan dari sebuah pengalaman akan membentuk hubungan yang kolaboratif dan berarti 
dalam proses konseling. Dengan demikin menjadi sangat penting dalam memfasilitasi hubungan teraupetik profesional yang seutuhnya memahami dan menghargai konteks dan perspektif individu. Tanpa menghargai konteks dan perspektif maka tidak mungkin ada empati dan kepercayaan yang terbentuk dalam proses konseling (Sanyata, 2006: 77).

Memang banyak pilihan pendekatan yang bisa dipakai dalam proses konseling, misalnya face to face dan lain sebagainya yang sifatnya konvensional, tetapi sekarang telah berkembang banyak pilihan metode dan tempat yang dimudahkan dengan alat komunikasi. Dengan adanya perkembangan teknologi dan komunikasi, maka konselor perlu mempelajari beberapa faktor penting dalam konseling yang efektif tergantung pada kualitas hubungan terapeutik (Illiyah, 2017: 73). Konselor diharapkan dapat memahami sifat manusia, mampu menganalisis dinamika hubungan, dan mendalami kejiwaan serta sikap empati merupakan faktor penentu untuk membangun hubungan terapeutik yang positif. Selain tujuan dan harapan bersama antara konseli dan konselor ada faktor lain yang perlu diperhatikan adalah media yang dipakai untuk memfasilitasi proses teraupetik diduga menjadi kunci untuk keberhasilan proses terapeutik.

Dengan munculnya internet, komunikasi telah merevolusi dan prinsip dasar hubungan manusia telah diintesifkan, diperluas dan menantang. Sekarang peluang sangat terbuka dan memberi kesempatan kepada orang untuk menjangkau keterhubungan dengan memanfaatkan web untuk mencari informasi, persahabatan, maupun layanan konseling secara profesional. Tren terus berubah dalam dan lintas generasi. Dewasa ini, yang lebih terlibat dalam dengan jejaring sosial adalah remaja dan mahasiswa.

\section{Konseling cyber bagi konteks masyarakat berbasis online}

Kemajuan teknologi, pengetahuan dan pergerakan zaman menuntut kita untuk terus melakukan inovasi (Isnawati \& Mutiara, 2018: 160). Dalam hal ini, kaitannya dengan konseling yang termasuk harus selalu berinovasi adalah para konselor yaitu pada saat melakukan kegiatan konseling. Teknologi mengacu pada modernitas (Rosana, 2017: 67). Dengan kata lain, teknologi menawarkan orang lebih banyak kesempatan untuk meng-upgrade semua jenis gaya hidup (Tilfarlioğlu, 2011: 64), dengan perkembangan teknologi tinggi dan globalisasi, sosial, budaya, aspek pendidikan kehidupan menjadi berbeda dan lebih baik dalam hal ruang waktu dan komunikasi (Tilfarlioğlu, 2011: 65). 
Dalam perkembangan teknologi informasi dan komunikasi interaksi antara konselor dan konseli tidak hanya terjadi dalam hubungan face to face tetapi dalam dilakukan secara virtual melalui internet (onlien) dalam bentuk "Konseling Cyber". Oleh karena itu konselor perlu beradaptasi dan mempersiapkan diri secara baik dalam penguasaan teknologi informasi dan komunikasi dalam melaksanakan pelayanan bimbingan dan konseling. Hal ini tidak lagi menjadi pilihan tetapi menjadi sebuah kewajiban untuk dilakukan oleh konselor mengingat perilaku masyarakat dewasa ini melaksanakan aktivitas basisnya pada teknologi informasi dan komunikasi.

Layanan Konseling Cyber adalah proses pemberian bantuan psikologis dari seorang konselor yang profesional kepada seorang konseli yang memiliki masalah dan tidak mampu menyelesaikan masalahnya sendiri c Sebagaimana telah dijelaskan sebelumnya bahwa Konseling Cyber perlu dilakukan karena Konseling Cyber harus dipahami sebagai sebuah strategi bimbingan dan konseling. Bloom (2004) menyebutkan bahwa layanan Konseling Cyber adalah salah satu strategi layanan konseling yang bersifat virtual atau konseling yang berlangsung melalui bantuan koneksi internet. Namun yang perlu diperhatikan adalah perangkat yang digunakan dalam cyber counselling itu sendiri. Tentu yang menjadi penentu utama adalah koneksi dengan internet supaya sehingga dapat terjadi interaksi melalui website, email, facebook, video conference atau yahoo massengger maupun dalam bentuk yang lainnya.

Konseling Cyber dapat didefinisikan sebagai praktek konseling profesional yang terjadi ketika konseli dan konselor berada secara terpisah dan memanfaatkan media elektronik untuk berkomunikasi melalui internet (Prasetiawan, 2016: 27). Definisi ini mencakup web, email, chat dan sebagainya. Dalam kondisi seperti ini memungkinkan terjadinya komunikasi antara dua pihak bisa lebih cepat, lebih efisien dan lebih nyaman dari sudut pandang administrasi.

Konseling Cyber adalah interaksi secara tidak langsung berbasis teks dalam pertukaran komunikasi terapeutik antara konseli dan konselor dengan menggunakan surat eletronik. Disebut berbasis teks hanya untuk membedakannya dari layanan konseling berbasis suara yang ditandai dengan komunikasi timbalbalik antara konseli dan konselor secara langsung. Kedua metode ini mengharuskan konselor dan konseli memiliki akses ke layanan internet. Banyak orang lebih mudah mengkomunikasikan pikiran dan perasaan mereka ketika mereka tidak teramati. Walaupun isyarat verbal dan non verbal tidak dirasakan, namun hubungan konseling dapat berlangsung. Untuk alasan ini, hubungan online 
dapat memiliki intensitas dan keintiman yang luar biasa, disebut sebagai "ikatan berbasis teks."

Cybercounselling dapat dibagi menjadi dua bagian besar yaitu yang bersifat noninteraktif dan interaktif (synchronous dan asynchronous). Non Interaktif, berupa situs yang berisi informasi dan narasumber self help atau pertolongan mandiri. Sedangkan yang interaktif synchronous adalah pelayanan konseling secara langsung seperti chat atau instant messaging, dan video conference. Interaktif asyncronous yang secara tidak langsung berupa terapi email dan Bulletin Boards Counselling Interaktif: konseling yang berjenis interaktif adalah situs yang menawarkan alternatif bentuk terapi melalui internet, dimana terdapat interksi antara konseli dan konselor baik secara langsung maupun tidak langsung (Prasetiawan, 2016: 28-32)

Kraus, R., Stricker, G., \& Speyer, C. (2010) menjelaskan bahwat Teks Chat memungkinkan konselor untuk berkomunikasi dengan seorang konseli secara real time melalui Internet. Teks-chatting adalah komunikasi lanjutan line-by-line, dengan konselor dan konseli berkomunikasi bersama. Chatting adalah salah satu teknologi internet tertua. Sebagai konselor online, mungkin akan menggunakan chatting sebagai cara dalam konseling. Konselor online dapat chatting dengan konseli melalui web chat room (termasuk di dunia maya) atau perbincangan terpisah melalui antara klien. Chat dapat difasilitasi oleh aplikasi berbasis web pesan singkat (instant messenger) atau program pesan singkat (instant messaging). Banyak sistem telah dikembangkan untuk memungkinkan pesan instan (chatting). Google Talk, iChat, Skype, AOL Instant Messenger (AIM), dan Microsoft Messenger adalah beberapa layanan IM yang paling umum (Kraus et al., 2010: 7).

Kraus, R., Stricker, G., \& Speyer, C. (2010) menjelaskan bahwa terapi kelompok di chat room menjadi lebih menantang, yang mirip dengan memfasilitasi kelompok dimana saling terpisah tapi suara masing-masing anggota kelompok masih dapat terdengar. Dengan sinkron chatting, hilangnya isyarat pendengaran, meninggalkan terapis mengandalkan isyarat visual. Di Chat room, yang digulir baik dari atas ke bawah atau bawah ke atas, seringkali sulit untuk "melihat" semua anggota dalam kelompok pada satu waktu. Kedua fasilitator dan konseli cenderung tetap memperhatikan entri berikutnya. Sementara fasilitator hadir untuk satu anggota grup dengan mengetik jawaban, entri chat lainnya mungkin terlewatkan, membutuhkan fasilitas scroll kembali dan menemukan mereka. Memegang chatting diskusi dengan lebih dari beberapa peserta dapat menjadi menantang karena kurangnya visibilitas langsung dan komunikasi terkait isyarat. Meski 
begitu, terapi kelompok dalam chat room dapat menjadi cara yang sangat dinamis untuk memberikan layanan terapi kelompok (Kraus et al., 2010: 8).

Kraus, R., Stricker, G., \& Speyer, C. (2010) melalui ikatan berbasis teks, dan dengan kehadiran dirasakan terapis, konseli dapat mengalami kebebasan ekspresi diri dan pertumbuhan kesadaran diri yang sangat berarti dari dialog online (Kraus et al., 2010: 9). Kemajuan tergantung pada penerimaan dan pemahaman dalam menghormati masalah konseli, kesungguhan dalam menulis teks merupakan kualitas diri dari terapis yang nyata. Efek rasa malu atau merasa sangat berhatihati basanya menjadi percakapan diawal proses terapi dimulai.

Interpretasi kata-kata konseli dalam percakapan adalah keterampilan yang membutuhkan latihan dan keterampilan khusus dalam intervensi, terutama dengan sifat percakapan dari media. Ada risiko prematur interpretasi, yang dapat meleset, terutama mengingat rasa malu dan efek pada sisi terapis. Namun, aliran dialog spontan dapat memberikan terapis dengan jendela ke proses bawah sadar yang mungkin menjadi jelas sebagai konseli sedang mengetik dan mengungkapkan keadaan pikiran yang tidak harus bersuara secara face to face.

Tanpa kehadiran fisik atau suara, ada kemungkinan bahwa fantasi dari konselor dan biasanya ideal akan mengembangkan, yang mungkin membesarbesarkan faktor transferensi. Sementara belum tentu memiliki pengaruh signifikan pada pekerjaan terapeutik, tentu harus ada keberatan oleh terapis ketika terlibat dalam terapi secara online dan ditangani langsung saat diperlukan. Menurut Huzili, Ahmad \& Othman menyebutkan potensi manfaat layanan cybercounselling dapat mencakup: (1) konseli dapat mengirim dan menerima pesan setiap saat, siang atau malam dan di setiap tempat, (2) konseli mampu mengambil selama mereka ingin menulis, dan memiliki kesempatan untuk merenungkan pesan, (3) konseli secara otomatis memiliki catatan komunikasi untuk merujuk nanti, dan 4) konseli merasa kurang introvert dari secara pribadi.

Ada berbagai cara dimana konseling dan psikoterapi secara tradisional ditawarkan, dalam keragaman konteks. Namun, perkembangan zaman menuntut konselor bahkan konseli agar dapat menyesuaikan diri dengan perkembangan teknologi informasi dan komunikasi. Perkembangan ini dilatarbelakangi oleh konteks kekinian yang mengharuskan proses layanan konseling tidak selamanya terjadi hanya dengan face to face secara langsung dalam ruang dan waktu yang sama. Tetapi proses konseling dapat terjadi secara terpisah antara konselor dan konseli dalam ruang dan waktu yang berbeda. Dipihak lain perilaku masyarakat dewasa ini khususnya remaja dan mahasiswa lebih sering menggunakan layanan 
internet sebagai sebuah sarana yang efektif dalam mengakses informasi dan bantuan terkait dengan permasalahan yang dihadapi.

Konselor online memiliki posisi yang unik dalam proses layanan terapeutik, karena dalam keadaan yang terpisah diharapkan dapat membaca gejala-gejala prsikologis konseli. Oleh karena itu, dibutuhkan seperangkat keterampilan yang matang dari konselor online dalam melaksanakan pelayanan secara online. Konselor harus dipandu oleh rencana pelayanan yang mengkombinasikan kemampuan empatik dengan media yang digunakannya. Keefektifan konseling secara online dapat dibuktikan dengan terjadinya perubahan perilaku yang ditunjukkan oleh konseli melalui penerimaannya terhadap konselor.

Sebagai konselor online perlu memiliki pengetahuan yang lebih besar dari teori dan praktek kesehatan mental, dan untuk dilatih dan diawasi sesuai dengan persyaratan profesi pada umumnya. Hanya dengan cara itulah konselor dapat dapat benar-benar memahami dan berempati dengan konseli online. Konselor online memiliki kemampuan tidak hanya untuk mengatasi peristiwa-peristiwa penting dalam kehidupan konseli saat terjadi baik online, tetapi juga harus dapat memahami kata-kata konseli (secara tertulis), mendorong penggunaan ekspresi kreatif (misalnya, menggunakan warna font dan grafis), menggabungkan pengelaman selama layanan (misalnya, email dan chatting atau telepon), dan memberikan dukungan, dan sumber informasi, yang banyak tersedia secara online. Oleh karena itu, konselor hanya memiliki banyak strategi untuk membantu konseli dalam penemuan diri, penyembuhan diri, dan pencapaian tujuan konseling yang diharapkan (Petrus \& Sudibyo, 2017: 9-10).

Tentu bukanlah hal yang mudah dalam mengelola cyber counselling seperti parktek konseling yang lazimnya dilaksanakan. Dengan demikian bukan lalu berarti bahwa praktek konseling yang lazimnya dilaksanakan adalah hal yang mudah. Keduanya memiliki kelebihan dan kekurangan masing-masing. Hanya saja yang mau ditekankan disini kesulitan pengelolaan cyber counselling adalah terkait dengan penguasaan teknologi yang harus dimiliki oleh konselor online.

Pengelolaan cybercounselling mengharuskan seorang konselor memiliki seperangkat pengetahuan teknis terkait dengan penguasaan internet dan segala perangkat yang terkait di dalamnya. Selain itu, seorang konselor juga perlu menguasai norma dan etika dalam penggunaan cyber counselling. Dan disadar dengan sungguh bahwa ini bukanlah hal yang mudah untuk dilakukan. Hal ini menjadi penting karena bersentuhan langsung dengan aspek kerahasiaan data dan riwayat proses layanan konseling secara online. 
Dalam implementasi cybercounselling beberapa masalah yang mungkin timbul dan harus diwaspadai secara cermat antara lain:

Isu-isu etika, yaitu hal-hal yang terkait dengan kode etik konseling yang harus ditaati oleh konselor maupun pihak lainnya. Hal-hal yang terkait dengan isu etika antara lain menyangkut: (a) keharasiaan, (b) validitas data, (c) penyalahgunaan komputer oleh konselor, (d) kekurangpahaman konselor tentang lokasi dan lingkungan konseli, (e) keseimbangan akses terhadap internet dan jalan raya informasi, (f) kepedulian terhadap privacy (kerahasiaan pribadi), (g) kredibilitas konselor.

Isu-isu pengembangan hubungan konseling, yaitu isu yang terkait dengan hubungan antara konselor dengan konseli secara tatap muka sebagai tindak lanjut dari konseling yang dilakukan melalui internet. Ada kalanya konselor dan konseli merasa perlu adanya pertemuan tatap muka sebagai tindak lanjut dari interaksi melalui internet. Hal itu dapat dilaksanakan sesuai dengan kesepakatan konselor dan konseli atau dapat diatur secara khusus (Kraus et al., 2010: 93-97).

\section{Simpulan}

Layanan konseling cyber adalah salah satu strategi layanan konseling yang bersifat virtual atau konseling yang berlangsung melalui bantuan koneksi internet. Konseling Cyber adalah jawaban dimana dewasa ini, hampir bisa dipastikan bahwa setiap orang yang memiliki telepon pintar, juga mempunyai akun media sosial, seperti Facebook, Twitter, Path, Instagram, dan sebagainya. Kondisi ini seperti sebuah kelaziman yang mengubah bagaimana cara berkomunikasi pada era serba digital seperti sekarang termasuk pelaksanaan konseling. Perkembangan ini dilatarbelakangi oleh konteks kekinian yang mengharuskan proses layanan konseling tidak selamanya terjadi hanya dengan face to face secara langsung dalam ruang dan waktu yang sama. Tetapi proses konseling dapat terjadi secara terpisah antara konselor dan konseli dalam ruang dan waktu yang berbeda. Dalam implementasi konseling cyber mendapati beberapa masalah seperti Isu-isu etika dan Isu-isu pengembangan hubungan konseling. Konselor cyber sebaikanya memiliki kemampuan tidak hanya mengatasi peristiwa-peristiwa penting dalam kehidupan konseli tidak hanya saat online saja, tetapi juga harus dapat memahami kata-kata konseli (secara tertulis), mendorong penggunaan ekspresi kreatif (misalnya, menggunakan warna font dan grafis), menggabungkan pengelaman selama layanan (misalnya, email dan chatting atau telepon), dan memberikan dukungan, dan sumber informasi, yang banyak tersedia secara online. 


\section{Daftar Pustaka}

Ahmad, A. (2013). Perkembangan Media Online dan Fenomena Disinformasi (Analisis pada Sejumlah Situs Islam) Online Media Development and Phenomenon of Disinformation (Analysis of Islamic sites). Jurnal Pekommas, 16 No. 3. Retrieved from https://jurnal.kominfo.go.id/ index.php/pekommas/ article/view/1160305

Arifin, M. (1976). Pokok-Pokok Pikiran Tentang Bimbingan dan Penyuluhan Agama di Sekolah dan Luar Sekolah. Jakarta: Bulan Bintang.

Christakis, N., \& Fowler, J. H. (2009). Connected: Dasyatnya Kekuatan Jejaring Sosial Mengubah Hidup Kita. Jakarta: Gramedia.

Corey, G. (2012). Theory and Practice of Counselling and Psychotherapy (9th ed.). Cengage Learning.

Djumhur, L., \& Surya, M. (1978). Bimbingan dan Penyuluhan diSekolah Guidance and Conseling. Bandung: Ilmu.

Gunarsa, S. (1988). Psikologi untuk Membimbing. Jakarta: Gunung Mulia.

Henry, J., \& David, T. (2003). Democracy and The New Media In Transition. London: MIT Press.

Illiyah, M. (2017). Konseling Anak Dengan Terapi Menggambar Dalam Membentuk Konsep Diri Positif Anak Di Tpa Ash Shuffah Wonocolo Surabaya (undergraduate). UIN Sunan Ampel Surabaya. Retrieved from http://digilib.uinsby.ac.id/15044/

Isnawati, Z. \& Mutiara, K.E. (2018). Metode Dongeng Dan Pembentukan Jiwa Religius Anak Penyandang Tuna Grahita Ringan. ThufuLA : Jurnal Inovasi Pendidikan Guru Raudhatul Athfal, Vol 6, No 1, Hal 159-173

Kraus, R., Stricker, G., \& Speyer, C. (Eds.). (2010). Online counselling: a handbook for mental health professionals (2nd ed). Amsterdam; Boston: Academic Press.

Madhal, H. (2008). Hadits BKI. Yogyakarta: Amanah.

Mulawarman, \& Nurfitri, A. D. (2017). Perilaku Pengguna Media Sosial beserta Implikasinya Ditinjau dari Perspektif Psikologi Sosial Terapan. Buletin Psikologi, 25(1), 36. https://doi.org/10.22146/buletinpsikologi.22759

Nasrullah, R. (2015). Media sosial (perspektif komunikasi, budaya, dan sosioteknologi). Jakarta: Simbiosa Rekatama Media.

Paimun. (2008). Bimbinan dan Konseling. Jakarta: UIN) Syarif Hidayatullah.

Papacharissi, Z. (2011). A Networked Self: Identity, Community, and Culture on Social Network Sites. New York: Routledge.

Petrus, J., \& Sudibyo, H. (2017). Kajian Konseptual Layanan Cyberconseling. 
Konselor, 6(1), 6. https://doi.org/10.24036/02017616724-0-00

Prasetiawan, H. (2016). Cyber Counselling Assisted With Facebook To Reduce Online Game Addiction. GUIDENA: Jurnal Ilmu Pendidikan, Psikologi, Bimbingan Dan Konseling, 6(1), 28-32. https://doi.org/10.24127/gdn.v6i1.409

Rogers, E. M. (2003). Diffution of Innovation. New York: Routledge.

Rosana, E. (2017). Modernisasi Dalam Perspektif Perubahan Sosial. Al-Adyan, $10(1), 67-82$.

Sanyata, S. (2006). Perspektif Nilai Dalam Konseling : Membangun Interaksi Efektif Antara Konselor - Klien. Paradigma, 1(02). Retrieved from https://journal.uny.ac.id/index.php/paradigma/article/view/5946

Shields, R. (2003). Virtual: Sebuah Pengantar Komprehensif. Yogyakarta: Jalasutra.

Soeparno, K. (2016). Social Psychology: The Passion Of Psychology. Buletin Psikologi, 19(1). https://doi.org/10.22146/bpsi.11544

Sukardi, D. K. (1995). Proses Bimbingan dan Penyuluhan di Sekolah. Jakarta: Rineka Cipta.

Tilfarlioğlu, F. Y. (2011). An International Dimension of the Student's Attitudes towards the Use of English in Web 2.0 Technology. The Turkish Online Journal of Educational Technology, 10(2). Retrieved from http://www.tojet.net/volumes/v10i3.pdf

Walgito, B. (1989). Bimbingan dan Penyuluhan di Sekolah. Yogyakarta: Andi Offset.

Winkel, W. S. (2005). Bimbingan Dan Konseling Di Institusi Pendidikan. Jakarta: Media Abadi.

Yusuf, S., \& Nurihsan, A. J. (2006). Landasan Bimbingan \& Konseling. Bandung: Remaja Rosdakarya. 